\title{
PENINGKATAN MOTIVASI DAN KEMAMPUAN MENULIS TEKS DESKRIPSI MELALUI PENDEKATAN PROSES SISWA KELAS VII SMP NEGERI 5 MAGELANG
}

\author{
Haryati \\ SMP Negeri 5 Magelang \\ email: h4ry4tis@gmail.com
}

\begin{abstract}
ABSTRAK
Penelitian ini bertujuan untuk meningkatkan proses pembelajaran, motivasi, dan kemampuan menulis teks deskripsi melalui penerapan pendekatan proses siswa Kelas VII SMP Negeri 5 Magelang. Penelitian ini merupakan penelitian tindakan kelas. Penelitian ini dilaksanakan tiga siklus. Subjek penelitian adalah siswa kelas VII SMP Negeri 5 Magelang tahun pelajaran 2016/2017 sejumlah 30 siswa. Pengumpulan data dalam penelitian ini menggunakan observasi, wawancara, tes, analisis dokumen, dan angket. Pengujian validitas data dalam penelitian ini dilakukan dengan cara trianggulasi. Teknik analisis data yang digunakan adalah teknik kuantitatif dan kualitatif. Teknik analisis data kuantitatif menggunakan teknik statistik deskriptif. Teknik analisis data kualitatif menggunakan deskriptif komparatif. Hasil penelitian dikemukakan sebagai berikut. 1) Proses pembelajaran meningkat, 2) Motivasi menulis siswa meningkat. 3) Penerapan pendekatan proses dapat meningkatkan kemampuan menulis teks deskripsi. Pada kegiatan pratindakan siswa yang mencapai ketuntasan belajar hanya 6 siswa (20\%), Siklus I menjadi 13 siswa (43\%), Siklus II meningkat menjadi 19 siswa (63\%), Siklus III mencapai 29 siswa (97\%). Adapun nilai rerata kemampuan menulis teks deskripsi siswa pada kegiatan pratindakan adalah 60 , pada siklus I rerata 66,7 , siklus II rerata70,8, dan siklus III rerata 78 .
\end{abstract}

Kata Kunci: motivasi, kemampuan menulis, teks deskripsi, pendekatan proses

\section{IMPROVING MOTIVATION AND WRITING CAPABILITY OF TEXT DESCRIPTION THROUGH OF PROCESS APPROACH TO GRADE VII STUDENTS OF SMP NEGERI 5 MAGELANG}

\begin{abstract}
This research aimed to improve the process learning, motivation and writing capability of writing the descriptive text through the implementation of the process approach of students of Class VII of SMP Negeri 5 Magelang. This research was a classroom action research. This action study was divided into three cycles. The research was conducted in SMP Negeri 5 Magelang in the academic year 2016/2017. The subjects were 30 students. Data collection techniques in this research used observation, interviews, tests, document analysis, and questionnaires. Testing the validity of data in this study was conducted by means of trianggulation, namely by using triangulation of data sources and data collection methods. Data analysis techniques used were quantitative and qualitative techniques. Quantitative data analysis techniques used descriptive statistical techniques. Qualitative data analysis techniques used descriptive comparative. The results are presented as follows. 1) Learning process 2) Motivation to write descriptive texts. 3) The implementation of process approach could improve the capability of writing descriptive text. In preaction activities students who had completed learning reached 6 students $(20 \%)$, in cycle I 13 students (43\%), in cycle II 19 students (63\%), and in cycle III 29 students $(97 \%)$. The mean score of students' writing capability before treatment was 60 , in cycle I 66.7, in cycle II 70.8, and in cycle III 78.
\end{abstract}

Keywords: motivation, writing capability, text description, process approach 


\section{PENDAHULUAN}

Menulis merupakan suatu proses kreatif memindahkan gagasan ke dalam lambanglambang tulisan (Semi, 2007: 14). Dalam pengertian ini menulis memiliki tiga aspek utama, yaitu tujuan atau maksud, gagasan, dan sistem pemindahan gagasan. Tarigan (2014: 3) mengungkapkan menulis merupakan salah satu kemampuan berbahasa yang bersifat ekspresif dan produktif. Menulis disebut produktif karena kemampuan tersebut digunakan untuk menyampaikan makna.

Kemampuan menulis telah diajarkan secara bertahap dari jenjang Sekolah Dasar, SMP, SMA/SMK sampai ke Perguruan Tinggi (Wardhana, 2007: .3). Bahkan Kurikulum 2013 Bahasa Indonesia digunakan sebagai sarana untuk mengembangkan kemampuan dan kemampuan menalar atau dikatakan Bahasa Indonesia sebagai penghela mata pelajaran yang lain. Kreativitas dalam menggunakan kalimat, dalam membuka, mengembangkan, dan menutup wacana atau teks menjadi hal penting yang harus dipertimbangkan. Demikian juga kejujuran berkarya menjadi aspek penting dalam penilaian pembelajaran menulis. Penilaian pembelajaran menulis dirancang agar dapat mengendalikan kejujuran berkarya. Oleh karena itu, tugas menulis perlu dikendalikan agar guru dapat mendeteksi orisinalitas tulisan siswa. Pembelajaran menulis selama ini masih terbengkelai dalam pendidikan Bahasa Indonesia (Alwasilah, 2013: .223). Pembelajaran menulis dijelaskan oleh Zainurrahaman (2011: 10) terjadi dalam proses teacher feedback, yaitu guru mengoreksi dan memberi masukan atas tulisan siswa tetapi tidak pernah direspon oleh siswa.

Pada umumnya siswa senang mengikuti pembelajaran mata pelajaran Bahasa Indonesia. Namun, berdasarkan wawancara dan observasi awal terhadap siswa dan teman sejawat pada tanggal 19 Agustus 2016, ditemukan permasalahan dalam materi menulis khususnya menulis teks deskripsi. Siswa merasa belum menguasai materi. Siswa merasa bingung untuk memerinci objek apalagi mengkonkretkannya. Siswa tidak berani bertanya, guru masih konvensional dalam mengajar, dan siswa tidak dapat mengawali menulis. Menulis merupakan kegiatan yang melelahkan sehingga siswa cepat bosan dan tidak fokus. Yang lebih parah ternyata guru pun enggan melaksanakan pembelajaran menulis.

Keengganan itu dapat disebabkan oleh dua faktor. Faktor yang pertama adalah ketidakmampuan guru sendiri dalam menulis. Hal ini menjadikan guru tidak tahu dengan jelas bagaimana semestinya menulis diajarkan, kecuali dengan memberikan teori tentang menulis kepada siswa dan meminta siswa menghasilkan tulisan sesuai dengan teori yang diberikan. Faktor kedua menurut Zainurrahman (2011: 10) adalah teacher feedback, bayangan beban mengoreksi dan memberi skor setelah tugas menulis diselesaikan oleh siswa.

Hamalik (2016: 157) memberikan penegas-an bahwa proses pembelajaran masih menitikberatkan pada metode imposisi, yakni pengajaran dengan cara menuangkan hal-hal yang dianggap penting oleh guru bagi murid. Hal ini tidak mempertimbangkan apakah bahan pembelajaran yang diberikan sesuai atau tidak dengan kesanggupan atau perkembangan, serta pemahaman murid. Banyak guru beranggapan bahwa penguasaan tata bahasa akan membuat siswa mampu menulis. Padahal, hal paling utama yang harus diajarkan adalah praktek menulis, bukan menjejalkan teori. Hal ini mengakibatkan kemampuan siswa dalam menulis semakin menurun dan hasilnya pun sangat mengecewakan. Rendahnya mutu dalam kemampuan menulis siswa disebabkan karena selama ini pembelajaran mengarang selalu dikesampingkan (Mustafa, 2016,: 2).

Berkaitan dengan masalah bagaimana meningkatkan proses pembelajaran agar siswa termotivasi dan mampu menulis, terutama menulis teks deskripsi pada siswa SMP N 5 Magelang, maka perlu dicarikan pemecahannya. Pemecahan itulah yang mendasari penulis melakukan penelitian tentang "Peningkatkan Motivasi dan Kemampuan Menulis Teks Deskripsi melalui Pendekatan Proses Siswa Kelas VII SMP N 5 Magelang". Pendekatan proses dapat menuntun siswa untuk lebih sistematis dalam menuangkan ide dan membuat kemampuan menulis siswa meningkat karena pendekatan proses dapat membuat siswa menvisualisasikan objek agar mudah dituangkan dalam tulisan. Tujuan penelitian ini adalah untuk menjelaskan peningkatan proses pembelajaran, motivasi dan kemampuan 
menulis teks deskripsi siswa kelas VII SMP N 5 Magelang dengan menggunakan pendekatan proses.

Tompkins (2010: 221) menjelaskan deskripsi sebagai tulisan yang seolah-olah melukis sebuah gambar dengan kata-kata. Sesuatu yang dapat dideskripsikan itu bukan hanya yang terjangkau oleh pancaindra, melainkan juga segala sesuatu yang dapat dirasakan dan dipikirkan. Deskripsi melukiskan sesuatu yang abstrak, yang emosional seperti kesedihan, kekacaubalauan, dan sebagainya. Pada hakikatnya deskripsi merupakan usaha untuk menggambarkan lukisan yang dirangkai dengan kata-kata (Akhadiah, Arsjad, \& Ridwan, 1993: 131).

Alwasilah (2013: 114) mengungkapkan deskripsi sebagai gambaran verbal ihwal manusia, objek, penampilan, pemandangan, atau kejadian. Cara penulisan ini menggambarkan sesuatu sedemikian rupa sehingga pembaca dibuat mampu (seolah merasakan, melihat, mendengar, atau mengalami). Tulisan deskripsi dijelaskan oleh Zainurrahman (2011: 45) sebagai tulisan yang bersifat menyebutkan karakteristikkarakteristik suatu objek secara keseluruhan, jelas dan sistematis. Tompkins melalui Zainurrahman (2011: .45) menyebutkan bahwa tulisan deskripsi adalah tulisan yang seolah-olah melukis sebuah gambar dengan menggunakan kata-kata. Tulisan deskripsi digunakan oleh penulis untuk menggambarkan sebuah keadaan atau situasi, karakter objek secara komprehensif, dengan mengandalkan kosakata.

Tujuan teks deskripsi menurut Tompkins (2010: 54) yaitu teks yang menggambarkan hasil pengamatan dengan rincian yang detail dengan menggunakan metafor dan perbandingan agar mudah dipahami. Dalam tulisan deskripsi pembaca dapat seolah-olah melihat, mengalami, merasakan apa yang dideskripsikan. Oleh karena itu siapa saja yang akan menulis teks deskripsi tidak hanya kaya kosakata tetapi juga harus mampu menggunakan kata yang sesuai dan hidup untuk memberikan sentuhan psikologis kepada para pembaca agar pembaca benar-benar memahami isi tulisan dan mencapai tujuan fungsionalnya. Hal ini oleh Zainurrahman (2011: 45) disebut sensory detail, yaitu penggambaran situasi objek secara detil dengan menggunakan kosakata tertentu yang mampu memberikan gambaran detil, dengan menggunakan kosakata tertentu yang mampu memberikan gambaran mental dari objek dan bisa dirasakan oleh pembaca.

Untuk bisa menulis dengan baik yang penting dimiliki oleh calon penulis adalah motivasi menulis itu sendiri. Motivasi menulis ibarat lokomotif yang akan menjadi pendorong dan penggerak bagi penulis untuk menghasilkan tulisan. Motivasi berkaitan erat dengan proses pembelajaran. Korb (2012: 2) mendefinisikan motivasi sebagai sesuatu yang mengarahkan atau menentukan atau mempengaruhi seseorang untuk melakukan sesuatu dan kondisi mental, kebutuhan internal, atau tujuan yang mengarah ke luar yang menyebabkan atau mendorong seseorang untuk bertindak. Sofyan (2012: 23) menjelaskan bahwa seorang anak yang telah termotivasi belajar sesuatu akan berusaha mempelajarinya dengan baik dan tekun untuk memperoleh hasil yang baik. Motivasi untuk belajar menyebabkan seseorang tekun belajar. Sebaliknya apabila seseorang kurang atau tidak memiliki motivasi belajar, dia tidak akan tahan lama belajar.

Beberapa faktor yang mempengaruhi prestasi belajar (Syah dalam Alpian, 2016: 3) adalah faktor internal dan faktor eksternal. Berdasarkan pendapat tersebut dapat dilihat jika faktor internal dan eksternal memiliki peran penting dalam menentukan kemampuan siswa pada berbagai tingkat kemampuan dan kompetensi yang dimiliki. Berbagai faktor yang berasal dari dalam diri siswa bisa berupa dorongan atau motivasi untuk melakukan kegiatan tertentu.

Menurut Sardiman (2011: 77), memberikan motivasi kepada seorang siswa berarti menggerakkan siswa untuk melakukan sesuatu atau ingin melakukan sesuatu. Pada tahap awal akan menyebabkan si subjek belajar merasa ada kebutuhan dan ingin melakukan sesuatu kegiatan belajar. Wlodkowski (2004: .18) menguraikan motivasi belajar sebagai sebuah sistem pembimbing internal yang berusaha menjaga fokus seorang anak tetap belajar serta berdiri sendiri dan bersaing melawan hal-hal lain dalam hidup sehari-hari. 
Trim (2016: 22) menjelaskan menulis bukan bakat alamiah tetapi dapat dilatihkan dengan syarat ada pengapian (motivasi), ada mentoring, dan ada pelatihan yang mendalam. Sabet (2014) mengungkapkan bahwa dengan motivasi yang tinggi akan dengan mudah menghasilkan tulisan. Menurutnya individu dengan kemampuan yang luar biasa tidak bisa mencapai tujuan jangka panjang tanpa motivasi yang cukup karena motivasi adalah salah satu faktor kunci. Namun, biasanya seseorang mempunyai hambatan ketika akan menulis.

Hambatan paling besar di dalam menulis adalah mengalahkan kemalasan. Jadi kalau rasa malas sudah bisa diatasi, yang lain bisa dipelajari. Shourafa (2012) menegaskan bahwa motivasi yang kuat menunjukkan kepercayaan diri terhadap kemampuan dan sikap positif terhadap efektivitas menulis dengan metode yang digunakan. Schunk (2012: 595) menjelaskan bahwa motivasi menulis bisa diperkuat dengan menggunakan tugas-tugas menulis autentik dan dengan menciptakan konteks pendukung untuk menulis. Membangun lingkungan kelas yang membangun efikasi-diri merupakan cara yang tepat untuk mengembangkan penulisan. Menulis melibatkan bahasa dan mencerminkan pikiran seseorang dan proses kognitif, menulis dipandang sebagai cara untuk meningkatkan kemampuan belajar dan pencapaian akademik.

Untuk mengatasi berbagai permasalahan tersebut, maka dipilihlah pendekatan proses. Pendekatan proses, yakni pendekatan pembelajaran menulis yang menekankan proses menulis. Fokus utama dalam pendekatan proses adalah bagaimana penulis menemukan, mengembangkan, dan memperbaiki teks. "Pendekatan proses pada dasarnya menekankan aspek proses sebagaimana dilalui oleh seorang penulis secara riil" (Zainurrahman, 2011: 8). Proses menulis terdiri atas beberapa langkah yang harus dilalui oleh seorang penulis. Tanpa melalui langkah-langkah ini, tidak mungkin sebuah tulisan yang baik dapat diciptakan. Tompkins \& Hoskisson (1995: .211) menyajikan lima tahap dalam proses menulis, yaitu tahap pramenulis, penulisan draf, merevisi, menyunting, dan publikasi.

Fokus utama pendekatan proses adalah bagaimana penulis menemukan, mengembangkan, dan memperbaiki teks Pendekatan yang akan digunakan dalam penelitian ini adalah pendekatan proses. Pendekatan proses dalam menulis, terutama penulis pemula, mudah diikuti. Siswa (atau siapa saja yang akan menulis) akan memahami dan melakukan dengan cepat hal-hal yang harus dipersiapkan dan dilakukan dalam menulis. Pendekatan ini pun sangat membantu pemahaman dan sikap, baik guru maupun siswa, bahwa menulis merupakan suatu proses dan hasilnya diperoleh secara bertahap. Artinya untuk menghasilkan tulisan yang baik umumnya orang melakukannya berkali-kali. Apalagi untuk menyusun teks deskripsi siswa harus dapat mengkonkretkan hasil penginderaan. Hal ini akan meningkatkan proses pembelajaran karena siswa menjadi bersemangat. Jika siswa bersemangat akan mewujudkan hasil yang maksimal.

Pendekatan proses diasumsikan tepat untuk pembelajaran menulis teks deskripsi. Pendekatan proses menurut Tompkins (2010: 52-60) merupakan suatu pendekatan dalam pembelajaran menulis dengan beberapa tahapan. Tahapan-tahapan tersebut adalah pramenulis, menulis draf, merevisi, menyunting, dan publikasi. Dalam pelaksanaannya, pendekatan proses dalam menulis menurut Tompkins (1995: 7) disajikan dalam lima tahap, yaitu: (1) pramenulis, (2) membuat draf, (3) merevisi, (4) menyunting, dan (5) mempublikasikan. Langkah-langkah tersebut dapat diuraikan sebagai berikut.

\section{Pramenulis}

Pramenulis adalah tahap persiapan untuk menulis. Tahap ini sangat penting dan menentukan dalam tahap-tahap menulis selanjutnya. Sebagian besar waktu menulis dihabiskan dalam tahap ini. Adapun hal-hal yang dilakukan siswa dalam tahap ini sebagai berikut: (1) memilih topik; (2) melakukan kegiatan-kegiatan latihan sebelum menulis; (3) mengidentifikasi pembaca tulisan yang akan mereka tulis; (4) mengidentifikasi tujuan kegiatan menulis; (5) memilih bentuk tulisan yang tepat berdasarkan pembaca dan tujuan yang telah ditentukan.

Siswa diberi kebebasan untuk menentukan topik berdasarkan pengamatan objek lingkungan sekolah. Sebelum menulis, siswa perlu memahami tujuan menulis yang akan mereka 
lakukan dan untuk siapa tulisan itu dibuat. Guru dapat memberi penjelasan bahwa tulisan yang akan siswa buat adalah tulisan deskripsi yang menggambarkan suatu tempat.

\section{Menulis Draf}

Pada tahap ini siswa diminta mulai mengekspresikan idenya tentang objek yang sudah diamati ke dalam bentuk tulisan sederhana. Pada waktu menulis draf ini, aspek-aspek teknis menulis seperti ejaan, penggunaan istilah, atau struktur kalimat tidak diperhatikan oleh siswa. Siswa lebih memfokuskan diri pada penyusunan ide, gagasan dengan gaya bahasa mereka masing-masing. Siswa bebas menuangkan ide atau gagasan tanpa memperhatikan aspek teknis menulis, agar mereka tidak akan merasa takut gagal dalam menulis.

\section{Revisi}

Pada tahap ini, siswa memperbaiki ide-ide mereka dalam teks. Merevisi bukanlah membuat teks menjadi lebih halus, tetapi kegiatan ini lebih berfokus pada penambahan, pengurangan, penghilangan, dan penyusunan kembali isi teks sesuai dengan kebutuhan dan keinginan pembaca. Inti kegiatan yang dilakukan siswa pada tahap revisi adalah sebagai berikut: (1) membaca ulang tulisan sederhana; (2) berbagi pengalaman tentang draf sederhana tulisan mereka dengan teman atau berdiskusi dengan guru; (3) mengubah tulisan dengan memperhatikan masukan dari teman atau guru sebagai upaya perbaikan tulisan itu.

Setelah menyelesaikan draf sederhana, siswa memerlukan waktu untuk istirahat dan menjauhkan diri dari teks mereka. Setelah itu, barulah siswa membaca kembali draf sederhana mereka dengan pikiran yang segar. Ketika siswa membaca inilah, mereka membuat perubahan menambah, mengurangi, menghilangkan atau memindahkan bagian-bagian tertentu dalam draf teks. Bisa juga menandai bagian-bagian yang akan diubah itu dengan memberinya tandatanda tertentu atau simbol, atau dengan menggarisbawahi. Agar rangkaian kegiatan revisi lebih efektif dan efisien, guru dapat membagi siswa menjadi kelompok-kelompok untuk bertukar pikiran tentang draf sederhana yang telah mereka buat.
Rangkaian kegiatan dalam kelompok ini adalah: (1) penulis membaca tulisannya; (2) para pendengar (siswa lainnya) memberi komentar; (3) penulis membuat pertanyaan; (4) pendengar memberi masukan; (5) proses diulang sampai semua anggota kelompok mendapat giliran yang sama untuk tampil membacakan tulisannya; (6) penulis merencanakan revisi berdasarkan komentar pendengar. Guru dapat membantu siswa dengan berkeliling dan memonitor tiap kelompok. bila siswa mendapat kesulitan dalam merevisi, guru dapat memberi komentar atau masukan.

\section{Menyunting}

Fokus dari tahap menulis ini adalah mengadakan perubahan-perubahan aspek karangan. siswa memperbaiki teks mereka dengan memperbaiki ejaan atau kesalahan yang lain. Tujuannya adalah untuk membuat teks lebih mudah dibaca orang lain. Pada tahap penyuntingan, siswa diminta untuk: (1) membaca ulang tulisan yang telah direvisi baik sendiri atau berupa masukan dari orang lain; (2) mengidentifikasi kesalahan tulisan dengan bantuan teman atau guru; (3) memperbaiki tulisan sehingga menjadi tulisan yang baik; (4) Penyuntingan dapat dilakukan secara individu atau dengan bantuan orang lain.

\section{Publikasi}

Pada tahap publikasi siswa diminta untuk membacakan hasil akhir tulisan, siswa lain sebagai pendengar dan memberi kritik atas tulisan yang dibaca. Apabila publikasi secara lisan tidak dapat diberikan karena pertimbangan waktu yang sedikit sehingga belum tentu semua hasil akhir tulisan memperoleh kesempatan yang sama, maka publikasi dapat ditempuh dengan cara menjilid tulisan tersebut. Keuntungan publikasi yang kedua ini adalah semua hasil akhir tulisan mendapat kesempatan yang sama. Artinya tulisan akhir yang kurang baik pun mendapat penghargaan dari semua pihak.

Menurut Tompkins \& Hoskisson (1995: 6) tahap-tahap yang terdapat dalam proses menulis itu tidak merupakan kegiatan yang linier. Pada dasarnya proses menulis bersifat nonlinier, merupakan suatu putaran yang ber-ulang. Ini berarti setelah penulis merevisi 
tulisannya mungkin ia melihat ke tahap sebelumnya, misalnya ke tahap pramenulis untuk melihat kesesuaian isi tulisan dengan tujuan menulis.

Di samping itu, dalam pelaksanaannya, setiap siswa mungkin akan berada pada tahap menulis yang tidak sama, walaupun sebagian besar siswa mungkin ada pada tahap yang sama. Hal ini dimungkinkan karena karakteristik setiap siswa berbeda, ada yang cepat berpikir, ada yang lambat, ada yang selalu meminta bantuan orang lain, ada yang mandiri, dan sebagainya. Guru sebagai kolabolator, bukan pemimpin kelas, harus dapat mengakomodasikan setiap karakteristik siswa. Guru hendaknya dapat menolong perkembangan kemampuan menulis setiap siswa semaksimal mungkin. Tahap-tahap menulis seperti yang disarankan tersebut, dilakukan dalam pembelajaran menulis dengan pendekatan proses di atas. Keterlibatan siswa dalam setiap kegiatan itu sangat berharga dan berguna untuk peningkatan motivasi dan perkembangan kemampuan menulis siswa dalam menulis dapat meningkat.

Guru dapat membantu siswa dengan berkeliling dan memonitor setiap kelompok. Pendekatan proses ini dapat membantu siswa memahami dan menghayati setiap proses dalam menulis dari menentukan topik, mengembangkan tulisan, menghapus dan menambah gagasan, hingga akhirnya menjadi satu tulisan utuh. Pendekatan proses menyebabkan siswa lebih bersemangat dalam menulis teks deskripsi. Oleh karena itu, pendekatan proses diharapkan mampu meningkatkan motivasi dan kemampuan menulis teks deskripsi siswa.

Sutama (2016: 20) menjelaskan bahwa pendekatan proses tidak bersifat linear, tetapi bersifat rekursif. Zainurrahman (2011: 8) menjelaskan bahwa proses rekursif adalah proses yang meniscayakan adanya perulangan di beberapa bagian. Sutama (2016) menjelaskan bahwa aktivitas yang akan dilaksanakan diawali dengan pramenulis, berdiskusi di dalam kelompok menulis, dan mencoba-coba menulis, sekaligus mengatasi kemacetan dalam menulis yang diakibatkan oleh keterbatasan memori.

Dengan penerapan pendekatan proses dalam pembelajaran menulis, sangat membantu siswa memahami proses menulis dan membangun repertoir strategi pramenulis, menulis, meninjau, dan menulis ulang. Dengan pendekatan proses siswa dituntut menjalani proses ini dengan harapan siswa dapat menghasilkan tulisan yang baik. Bahkan dengan pendekatan proses, kekurangan siswa dalam hal pengetahuan tentang topik yang akan ditulis akan teratasi, kelancaran siswa dalam menulis tidak akan terganggu oleh hal-hal yang bersifat gramatikal, dan kerendahan mutu tulisan akan dapat ditingkatkan. Trim (2016:32) menegaskan bahwa melalui pendekatan proses yang lebih mengutamakan proses akan menemukan jalan untuk menguasai kemampuan menulis secara tepat dan cepat. Sebaliknya, tanpa proses dan lebih berorientasi hasil siswa akan kehilangan makna belajar.

Sutama (2016: 81) menegaskan bahwa dengan pendekatan proses beban berat mengoreksi dan menskor tulisan siswa dapat diatasi. Zainurrahman (2011: 10) menyebutnya dengan peer feedback atau siswa sebaya yang menjadi responder, yaitu menyediakan siswa untuk berbagi tulisan, sama-sama membaca tulisan teman, dan memberikan masukan yang konstruktif sebagai dasar revisi tulisan-tulisan tersebut.

Shourafa (2012) mempertajam hal tersebut dengan penjelasannya bahwa siswa yang mempunyai motivasi menunjukkan tingkat kepercayaan diri yang kuat dan sikap positif terhadap pendekatan atau metode yang digunakan dalam pembelajaran menulis. Artinya siswa sangat termotivasi dengan adanya pengulangan dan sering berlatih. Dengan kata lain menurut Korb (2012: .6) usaha itu akan lebih bernilai dibanding hasil. Mereka perlu untuk merangkak terlebih dulu, sebelum bisa berjalan dan berlari. Pendekatan proses diasumsikan dapat mengatasi permasalahan siswa untuk meningkatkan motivasi dan kemampuan menulis teks deskripsi.

\section{METODE}

Metode penelitian yang dipergunakan adalah penelitian tindakan kelas atau classroom action research. Penelitian tindakan kelas adalah penelitian tentang kelas sasaran dengan memanfaatkan interaksi, partisipasi dan kolaborasi antara peneliti, kolaborator, dan siswa sebagai subjek penelitian. Penelitian tindakan kelas merupakan salah satu strategi pemecahan 
masalah yang memanfaatkan tindakan nyata dalam proses pembelajaran di kelas. Tujuan dipilihnya jenis penelitian ini untuk meningkatkan proses pembelajaran, motivasi, dan kemampuan menulis teks deskripsi siswa kelas VII SMP N 5 Magelang dengan menggunakan pendekatan proses.

Penelitian ini dilakukan di SMP N 5 Magelang yang terletak di Kota Magelang, Jawa Tengah. Pelaksanaan kegiatan observasi lapangan dilaksanakan pada bulan November 2016 sampai dengan bulan Januari 2017.

Subjek penelitian ini adalah siswa kelas VII SMP Negeri 5 Magelang tahun pelajaran 2016/2017 yang berjumlah 30 siswa. Sementara itu, objek penelitian tindakan kelas ini adalah motivasi dan kemampuan menulis teks deskripsi siswa kelas VII SMP Negeri 5 Magelang.

Teknik pengumpulan data dilakukan dengan menggunakan observasi, catatan lapangan, angket, dan tes. Instrumen merupakan alat yang dipergunakan untuk mengumpulkan data penelitian. Instrumen penelitian ini adalah: lembar pengamatan, catatan lapangan, dokumentasi. Tes. Teknik yang digunakan untuk menganalisis data dalam penelitian tindakan ini adalah deskriptif. Prosedur penelitian ini dilaksanakan dengan berpedoman pada suatu rangkaian langkah-langkah yang terbagi atas tiga siklus.

\section{HASIL DAN PEMBAHASAN}

Hasil pelaksanaan penelitian berdasarkan perencanaan, tindakan dan observasi, refleksi tiap-tiap siklus.

\section{Proses Menulis Pratindakan}

Berdasar hasil angket informasi awal keterampilan menulis teks deskripsi siswa kelas VII SMP N 5 Magelang diperoleh keterangan sebagai berikut. Tingkat kesukaan siswa kelas VII SMP N 5 Magelang terhadap mata pelajaran bahasa Indonesia cukup tinggi. Namun, siswa tidak senang jika mendapat tugas menulis. Siswa juga tidak senang mendapat tugas menulis teks deskripsi. Siswa mau menulis hanya karena diberi penghargaan. Siswa merasa tidak tertantang dan tidak mau mengulang tugas menulis yang diberikan guru. Jika siswa mendapat tugas yang harus diselesaikan dengan cara berdiskusi justru hanya dimanfaatkan untuk bergurau.

Berdasarkan catatan lapangan saat pelaksanaan tes pratindakan, diketahui bahwa pada tahap pramenulis khususnya dalam pramenulis baru pada tahap memperhatikan perintah dari guru. Siswa langsung menuangkan dalam bentuk draf jadi temanya sehingga cenderung terlalu luas atau tidak fokus. Pada tahap revisi siswa belum mempunyai motivasi untuk membaca kembali hasil draf teksnya dengan sungguh-sungguh. Apalagi draf temannya karena waktu mereka habis untuk mengarang. Siswa tidak memiliki motivasi untuk melakukan penyuntingan karena siswa masih bingung membedakan antara merevisi dan menunyunting. Tahap publikasi mereka baru pada tahap membacakan hasil karyanya di depan teman sebangkunya, bukan di depan kelas.

Lembar observasi saat pratindakan menunjukkan belum terlihat sikap aktif dalam meminta masukan teman, dalam tahap pramenulis, membuat kerangka teks. Sikap aktif baru pada menjawab pertanyaan-pertanyaan yang dipandu oleh guru. Dalam membuat draf teks siswa aktif mengembangkan ide. Dalam tahap revisi siswa bingung dalam hal membacakan kembali hasil teksnya dan belum aktif melakukan revisi draf teks. Siswa belum meminta masukan dari teman. Siswa tidak aktif dalam tahapan penyuntingan dan publikasi.

Kondisi menulis teks saat pratindakan berbeda dengan kondisi setelah siswa mendapatkan tindakan. Setelah menggunakan media siswa lebih memperhatikan terhadap kegiatan mengarang. Waktu 2 kali 40 menit digunakan untuk mengarang dengan baik. Menyelesaikan mengarang dengan tahapan-tahapan menulis, sehingga hasilnya menjadi lebih baik. Siswa memiliki motivasi dan aktif dalam kegiatan mengarang. Hal ini dapat dilihat pada sikap siswa yang lebih memperhatikan, tenang dan tidak mengeluh saat mengerjakan tugas mengarang.

\section{Proses Menulis Siklus I}

Pada siklus I menunjukkan bahwa motivasi siswa sudah mulai muncul dimulai dari pramenulis sampai publikasi. Pada tahap 
pramenulis memberikan gambaran bahwa siswa memiliki motivasi dalam menyusun kerangka, menentukan judul. Siswa terlihat memiliki semangat dalam mengembangkan kerangka teks menjadi draf teks. Tahap membuat draf teks menggambarkan bahwa siswa bersemangat memadukan: judul, tema dalam sebuah draf. Tahapan revisi dimulai dengan semangat dengan membaca ulang hasil draf teks kemudian merevisi. Tahap penyuntingan dilakukan dengan semangat, untuk melakukan kegiatan penyuntingan dari hasil revisi, penyuntingan kesalahan mekanik dan bahasa kemudian dipublikasikan di depan kelas oleh beberapa siswa.

Siklus I memberikan gambaran terkait perhatian siswa terhadap kegiatan mengarang. Siswa memiliki perhatian terhadap penjelasan guru, petunjuk guru, memperhatikan media, memperhatikan pendapat teman dan memperhatikan masukan dari teman terhadap kerangka teks. Siswa dalam tahap penyuntingan memperhatikan hasil revisi, kaidah tata tulis yang benar. Publikasi dilakukan oleh siswa dengan membacakan teks yang sudah jadi.

Lembar observasi yang diisi saat pelaksanaan siklus I menunjukkan bahwa siswa dalam menjalankan tahap pramenulis memiliki sikap aktif dalam memberikan pendapat terhadap teman terkait dengan membuat kerangka teks. Siswa saling meminta masukan dari teman. Mengungkapkan ide awal. Siswa serius dalam mengembangkan kerangka teks menjadi draf kasar. Siswa aktif saat melakukan revisi dengan membaca dengan sungguh-sungguh hasil draf. Kegiatan penyuntingan dilakukan dengan cermat. Siswa aktif dalam melakukan publikasi.

\section{Proses Menulis Siklus II}

Siklus II ini dilakukan dengan menggunakan pendekatan proses. Motivasi siswa terlihat ketika membuat kerangka. Motivasi yang dimiliki siswa dalam tahap membuat draf terlihat pada saat mengembangkan kerangka teks. Siswa memiliki semangat untuk membuat draf. Tahap membuat draf teks menggambarkan bahwa siswa bersemangat memadukan: judul, tema dalam sebuah draf teks. Tahapan revisi dimulai dengan semangat dengan membaca ulang hasil draf teks kemudian merevisi.
Tahap penyuntingan dilakukan dengan semangat, untuk melakukan kegiatan penyuntingan dari hasil revisi, penyuntingan kesalahan mekanik dan bahasa kemudian dipublikasikan di depan kelas oleh beberapa siswa. Siklus II memberikan gambaran terkait perhatian siswa terhadap kegiatan mengarang. Siswa memiliki perhatian terhadap penjelasan guru, petunjuk guru, memperhatikan pendapat teman dan memperhatikan masukan dari teman terhadap kerangka teks. Siswa dalam tahap penyuntingan memperhatikan hasil revisi, kaidah tata tulis yang benar. Publikasi dilakukan oleh siswa dengan membacakan teks yang sudah jadi.

Lembar observasi yang diisi saat pelaksanaan siklus II menunjukkan bahwa siswa dalam menjalankan tahap pramenulis memiliki sikap aktif dalam memberikan pendapat terhadap teman terkait dengan membuat kerangka. Siswa saling meminta masukan dari teman. Mengungkapkan ide. Siswa serius dalam mengembangkan kerangka teks menjadi draf kasar. Siswa aktif melakukan revisi dengan membaca dengan sungguh-sungguh hasil draf. Kegiatan penyuntingan dilakukan dengan cermat. Siswa aktif dalam melakukan publikasi.

\section{Proses Menulis Siklus III}

Siklus III ini dilakukan dengan menggunakan pendekatan proses. Motivasi siswa meningkat ketika membuat kerangka. Motivasi yang dimiliki siswa dalam tahap membuat draf terlihat pada saat mengembangkan kerangka teks. Siswa memiliki semangat untuk membuat draf. Tahap membuat draf teks menggambarkan bahwa siswa bersemangat dan sangat menikmati memadukan: judul, tema dalam sebuah draf teks. Tahapan revisi dilaksanakan dengan semangat dengan membaca ulang hasil draf teks kemudian merevisi.

Tahap penyuntingan dilakukan dengan semangat, untuk melakukan kegiatan penyuntingan dari hasil revisi, penyuntingan kesalahan mekanik dan bahasa kemudian dipublikasikan di depan kelas oleh beberapa siswa. Siswa sudah bisa membedakan antara merevisi dan menyunting. Lembar observasi yang diisi saat pelaksanaan siklus III menunjukkan bahwa siswa dalam menjalankan tahap pramenulis memiliki sikap aktif dalam memberikan pendapat terhadap te- 
man terkait dengan membuat kerangka. Dengan kesadaran siswa saling meminta masukan dari teman. Siswa serius dalam mengembangkan kerangka teks menjadi draf kasar. Siswa aktif melakukan revisi dengan membaca dengan sungguh-sungguh hasil draf. Kegiatan penyuntingan dilakukan dengan cermat. Siswa aktif dalam melakukan publikasi.

\section{Proses Tindakan}

Proses tindakan merupakan proses pelaksanaan tindakan pembelajaran menulis teks deskripsi dengan menggunakan pendekatan proses. Proses tindakan disajikan dalam bentuk proses pembelajaran menulis teks deskripsi menggunakan pendekatan proses. Pelaksanaan tindakan dilakukan dalam tiga siklus, yang memerlukan waktu 12 kali pertemuan. Subjek penelitian, yaitu siswa kelas VII SMP N 5 Magelang yang berjumlah 30 siswa.

Penelitian tindakan ini terbagi dalam 3 siklus, yaitu siklus I, siklus II, dan siklus III. Setiap proses pembelajaran menulis teks deskripsi selalu diterapkan pendekatan proses. Pembelajaran menulis teks deskripsi diawali dengan pretes. Pretest dilaksanakan untuk mengetahui kondisi awal kemampuan siswa dalam menulis teks deskripsi. Pemberian tindakan dilakukan selama 4 kali dalam setiap siklus. Setiap siklus diakhiri dengan tes. Hal itu, dilakukan untuk mengetahui peningkatan kemampuan menulis teks deskripsi siswa setelah menggunakan pendekatan proses.

Langkah-langkah pembelajaran yang telah ditetapkan dalam perencanaan yaitu pendahuluan, pramenulis, menulis kerangka teks, merevisi, menyunting, mempublikasi. Siswa telah melakukan kegiatan sebanyak empat kali melalui proses pramenulis, menulis kerangka teks, merevisi, menyunting dan mempublikasi (dibaca di depan kelas).

Para siswa menampakkan keantusiasan dalam pembelajaran menulis dengan pendekatan proses. Meskipun demikian, tampak pula bahwa para siswa mengalami berbagai masalah. Masalah-masalah tersebut antara lain tampak ketika mereka memulai menulis teks, mereka mengalami kesulitan dalam menentukan judul, membuat kerangka teks, serta mengembangkannya. Oleh karena itu, kolaborator selalu men- jelaskan dan memberikan bimbingan kepada siswa dalam menulis teks deskripsi. Kolaborator juga melibatkan teman sekelasnya dalam mengatasi berbagai kesulitan dalam menulis tersebut. Selain itu, mereka juga mengalami kesulitan dalam mengikuti diskusi tentang pembahasan pendekatan proses dan penerapannya dalam pembelajaran menulis. Dalam mengikuti diskusi, sebagian besar siswa bersikap pasif dan hanya beberapa siswa yang bersikap aktif. Sikap pasif tersebut, tampaknya disebabkan oleh belum dipahaminya konsep pembelajaran menulis dengan pendekatan proses dan belum terbiasanya mereka dalam melakukan diskusi.

Permasalahan-permasalahan tersebut dapat diatasi setelah kolaborator memberikan penjelasan tentang pendekatan proses, memberikan motivasi dan arahan bahwa diskusi dan hasilnya sangat menentukan keberhasilan mereka dalam menulis. Tindakan tersebut ternyata dapat memberikan hasil yang cukup baik. Para siswa akhirnya menyadari pentingnya bertukar pikiran dan pengalaman dalam proses penulisan sebuah teks.

Praktik menulis teks deskripsi dengan pendekatan proses juga dapat diikuti dengan baik oleh siswa. Setelah dilakukan tindakan pada siklus pertama, walaupun belum maksimal, hasilnya menunjukkan bahwa kemampuan siswa dalam menulis teks deskripsi mengalami peningkatan, setelah diberi tindakan pada siklus pertama, nilai rata-rata hasil teks deskripsi siswa mengalami peningkatan. Hal itu dapat dilihat dari rata-rata pencapaian skor teks deskripsi mereka, yaitu dari 60 sebelum siklus pertama menjadi 66 setelah tindakan pada siklus pertama.

Pada pelaksanaan siklus II langkah tindakan yang dilakukan sesuai dengan rancangan yang telah disusun. Namun, siswa masih memiliki kesulitan dalam merevisi dan menyunting tulisan. Oleh karena itu, kolaborator sangat berperan dalam membantu siswa untuk merevisi isi tulisan dan menyunting aspek tulisan. Tindakan yang dilakukan telah menghasilkan perubahan yang positif dalam hal kemampuan menulis siswa dan sikap siswa terhadap pembelajaran menulis. Terdapat dampak positif yang tidak direncanakan yaitu pada saat pembelajaran menulis dilakukan siswa sering membaca 
dan berbicara secara langsung dengan teman atau guru untuk bertanya atau menyampaikan pendapatnya.

Tindakan yang dilakukan telah menghasilkan perubahan yang positif dalam hal kemampuan menulis siswa dan sikap siswa terhadap pembelajaran menulis. Siswa tampak tidak merasa terpaksa mengikuti pembelajaran menulis sehingga menimbulkan perasaan senang terhadapnya. Terdapat dampak positif yang tidak direncanakan yaitu pada saat pembelajaran menulis dilakukan siswa sering membaca dan berbicara secara langsung dengan teman atau guru untuk bertanya atau menyampaikan pendapatnya. Kolaborator dan siswa tidak merasa waktunya tersita untuk penelitian tindakan ini.

\section{Peningkatan Motivasi dan Kemampuan Menulis Teks Deskripsi dengan Pendekatan Proses}

Setelah digunakan pendekatan proses siswa lebih termotivasi untuk mengikuti kegiatan menulis. Munculnya motivasi bermuara dari keterlibatan siswa secara aktif dalam kegiatan menulis. Hal ini terjadi karena pendekatan proses pada dasarnya menekankan aspek proses sebagaimana dilalui oleh seorang penulis secara riil. Semangat terlihat ketika melakukan pengamatan terhadap objek, siswa melakukan dengan saksama, dan ketika guru membangkitkan skemata melalui tanya jawab, siswa dengan aktif menjawab pertanyaan-pertanyaan dari guru. Ketika proses pengedrafanpun siswa aktif melaksanakan tugas mereka. Padahal kita mengetahui bahwa pramenulis barangkali menjadi tahapan yang paling tidak dihiraukan dalam proses menulis. Kenyataannya, tahapan ini menurut Tompkins (1995: 11) justru sangat penting dan hal ini sudah dilakukan oleh siswa. Ketika siklus satu dilaksanakan masih bermain belum serius, tetapi siklus selanjutnya pada tahap ini mereka semakin antusias. Selanjutnya ketika melakukan pengeditan secara kelompok, siswa sudah antusias untuk menyelesaikan proses pengeditan. Keaktivan siswa semakin terlihat ketika pengeditan secara kelompok.

Schunk (2012: 33) menjelaskan bahwa motivasi dapat mempengaruhi seluruh fase pembelajaran dan kinerja belajar. Peningkatan motivasi menulis siswa terlihat dalam: (a) pe- ningkatan keterlibatan siswa dalam proses pembelajaran, (b) peningkatan kerja sama siswa dalam proses kelompok. Penggunaan pendekatan proses dalam penulisan teks deskripsi ternyata mampu menjadi stimulus yang kuat bagi siswa untuk meningkatkan kemampuan menulisnya pada tindakan selanjutnya. Artinya rendahnya kemampuan menulis teks deskripsi siswa sebenarnya masih dapat ditingkatkan dengan cara memberi rangsangan yang tepat. Pemberian reward sebagai rangsangan untuk meningkatkan penulisan deskripsi siswa ternyata cukup berarti. Siswa yang semula sulit menuangkan ide atau gagasannya ke dalam bentuk tulisan akhirnya mampu dengan lancar menuangkan idenya. Motivasi eksternal yang diberikan akhirnya menjadi motivasi internal yang menguntungkan bagi siswa karena akan selalu semangat dalam belajar.

Keberhasilan siswa dari siklus ke siklus yang merupakan hasil dari penelitian tindakan kelas ini dapat diketahui melalui ada tidaknya peningkatan hasil akhir dan aspek-aspek yang ada dalam tulisan deskripsi siswa. Setiap kali penulisan deskripsi, dalam penelitian tindakan kelas ini dilakukan evaluasi dan refleksi baik sebelum maupun sesudah implementasi tindakan. Hal ini menunjukkan bahwa tindakan pada setiap siklus memberi dampak positif terhadap kemampuan menulis deskripsi siswa. Peningkatan tersebut telah memenuhi standar ketuntasan minimal.

Pada siklus III pembelajaran keterampilan menulis teks deskripsi dengan pendekatan proses diterapkan dengan melakukan peningkatan pada penyuntingan. Pada Siklus I siswa belum bersungguh-sungguh dalam pembuatan draf karena saat pengamatan lebih banyak bergurau dan bingung dalam menyunting. Siklus II siswa lebih bersemangat dalam penyusunan draf dan mulai memahami kegiatan menyunting dan pada Siklus III siswa jauh lebih bersemangat baik dalam penyusunan draf maupun penyuntingan. Hasilnya setelah diadakan uji kompetensi siklus III siswa yang tuntas bertambah menjadi 29 siswa (96,6\%). Sebelumnya berjumlah 19 siswa $(63,3 \%)$. Mengalami peningkatan sejumlah 10 siswa (30\%). Adapun nilai rerata yang dicapai 78,2 . Mengalami peningkatan sebesar 8,2 dari sebelumnya yakni 70,8. Pada siklus III ini pen- 
capaian ketuntasan klasikal sebesar 75\% dan kriteria ketuntasan 71 telah tercapai sehingga penelitian tindakan kelas telah dinyatakan selesai. Untuk memberikan gambaran yang lebih jelas pencapaian ketuntasan belajar dapat dilihat grafik berikut ini.

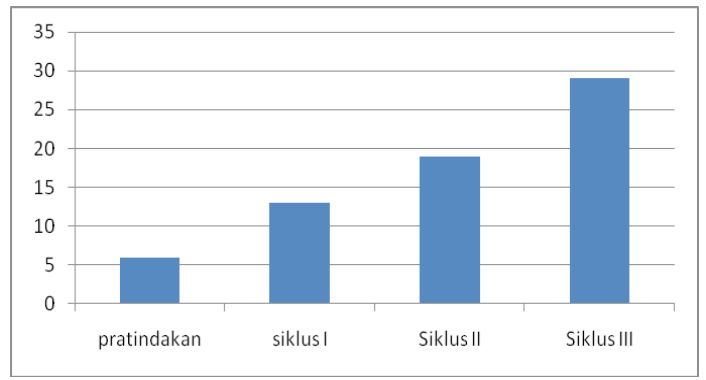

Gambar 1. Grafik Peningkatan Ketuntasan Belajar

Kemampuan menulis teks deskripsi siswa juga semakin meningkat, terbukti dengan meningkatnya nilai rerata kemampuan menulis teks deskripsi. Untuk memberikan gambaran yang lebih jelas tentang peningkatan nilai rerata kemampuan menulis teks deskripsi dapat dilihat grafik berikut ini.

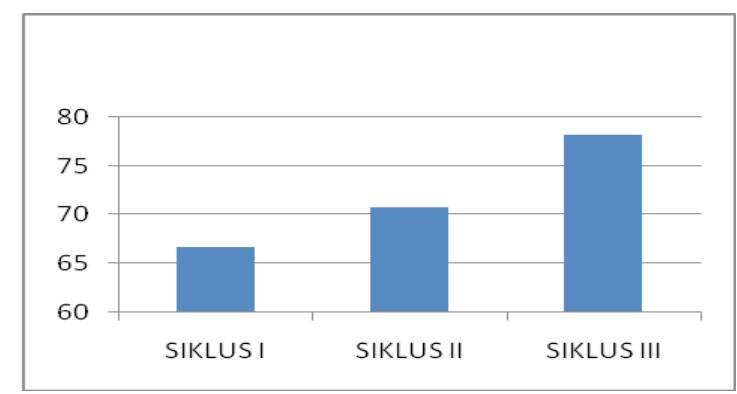

Gambar 2. Grafik Peningkatan Nilai Rerata Kemampuan Menulis

Berdasarkan hasil penelitian tindakan kelas di atas, tampak jelas bahwa secara teoretis maupun empiris hasil penelitian menggunakan pendekatan proses cukup bermanfaat dalam meningkatkan kemampuan menulis teks deskripsi. Secara teoretis tindakan-tindakan yang dilakukan didukung oleh teori-teori yang relevan dengan masalah yang sedang dihadapi. Secara empiris tindakan-tindakan yang dilakukan memiliki dampak yang bermanfaat bagi peningkatan kemampuan menulis teks deskripsi. Apabila sebelum penelitian ini dilaksanakan, para siswa belum memiliki kemampuan menulis teks deskripsi yang belum maksimal atau masih rendah. Namun, setelah dilakukan pembelajaran menulis teks deskripsi dengan pendekatan proses ada peningkatan secara memadai dari siklus I hingga siklus III.

Data-data tersebut mengandung makna bahwa kemampuan menulis teks deskripsi siswa telah mengalami peningkatan yang cukup signifikan antara sebelum diberi tindakan dan sesudah diberi tindakan pertama dan kedua cukup memberikan peningkatan terhadap kemampuan menulis teks deskripsi siswa. Dengan demikian, dapat dinyatakan bahwa penelitian tindakan ini telah mampu meningkatkan kemampuan menulis teks deskripsi siswa.

Pembelajaran kebahasaan, khususnya dalam peningkatan kemampuan menulis teks deskripsi menuntut guru untuk mampu memilih dan menentukan pendekatan yang tepat Dari hasil observasi dengan kolaborator, ternyata beliau mengalami kesulitan dalam melaksanakan pembelajaran khususnya kemampuan menulis teks deskripsi. Selama ini, guru masih menerapkan pendekatan tradisional dalam proses menulis teks deskripsi, di mana guru lebih menitikberatkan pada penyampaian materi teoritik daripada praktik menulis. Akibatnya, siswa tidak mempunyai pengalaman yang cukup dalam menulis. Selain hal itu, siswa cenderung kurang semangat dalam mengikuti kegiatan menulis.

Berdasarkan pemantauan kegiatan siklus I sampai kegiatan siklus III dapat dilihat adanya peningkatan kemampuan menulis teks deskripsi siswa dengan menggunakan pendekatan proses. Peningkatan tersebut dapat dilihat dari segi proses maupun dari segi kemampuan siswa dalam menulis teks deskripsi.

\section{Peningkatan Proses Pembelajaran}

Dari ketiga siklus yang dilaksanakan dalam penelitian ini, masing-masing siklus memiliki fokus dan bentuk tindakan yang berbeda. pada siklus I yang merupakan tahap pengenalan terhadap pembelajaran menulis teks deskripsi dengan pendekatan proses dan, siswa dibagi dalam bentuk kelompok. Meskipun siswa terbagi dalam bentuk kelompok, siswa tetap melakukan kegiatan menulis secara individu. 
Kerja kelompok hanya dilakukan pada saat merevisi serta mengedit kesalahan tulisan.

Kegiatan pramenulis yang terdiri dari pengamatan terhadap objek dan penyusunan ide tulisan dilakukan di dalam kelas. Fokus permasalahan yang akan diatasi adalah permasalahan yang dikemukakan guru pada saat prasurvei. Meskipun hasil tulisan siswa di siklus I belum optimal, namun siswa sudah mengalami sedikit peningkatan. Di samping itu, siswa yang menjadi subjek dalam penelitian ini mulai mengerti dan memahami tentang pembelajaran menulis teks deskripsi dengan pendekatan proses.

Pada siklus II kegiatan pramenulis tetap dilakukan di ruangan kelas. Fokus permasalahan yang ada pada pelaksanaan siklus sebelumnya. Dari hasil tulisan siswa di siklus I dapat diketahui aspek isi gagasan yang merupakan indikator dasar dari tulisan deskripsi yang terdiri dari penggambaran. Aspek menulis yang lain sudah menunjukkan peningkatan yang cukup berarti. Melalui kegiatan siklus III ini dapat diketahui tulisan siswa mengalami kemajuan yang berarti. Unsur penggambaran yang merupakan indikator dasar dari tulisan deskripsi telah tercipta dengan baik.

Secara keseluruhan, pelaksanaan penelitian tindakan kelas ini telah berhasil meningkatkan kemampuan siswa dalam menulis deskripsi. Hal ini ditandai dengan adanya peningkatan skor, baik pada akhir tindakan kegiatan siklus I maupun di akhir tindakan kegiatan siklus II dan III. Di samping itu, siswa tidak lagi mengalami kesulitan untuk menulis teks deskripsi. Siswa mengakui bahwa penggunaan pendekatan proses dapat melatih mereka untuk dapat menulis teks deskripsi dengan baik.

Pelaksanaan penelitian tindakan kelas ini juga memberikan manfaat bagi kolaborator. Guru mengakui bahwa penelitian tindakan kelas ini mampu meningkatkan skor menulis teks deskripsi anak didiknya. Pengalaman yang diperoleh selama melaksanakan penelitian ini juga dapat dibagikan pada sesama guru sehingga diharapkan dapat meningkatkan mutu pengetahuan dan kemampuan pengelolaan pembelajaran menulis .

\section{SIMPULAN}

Berdasarkan hasil penelitian serta pembahasan dalam Penelitian Tindakan Kelas ini, dapat disimpulkan sebagai berikut:

Tindakan berupa penggunaan pendekatan proses mampu meningkatkan proses pembelajaran, motivasi, dan kemampuan menulis teks deskripsi siswa. Pelaksanaan tindakan selama tiga siklus dapat meningkatkan proses pembelajaran menulis teks deskripsi. Siswa mampu menuangkan ide atau gagasannya dengan lancar. Selanjutnya hasil penelitian secara rinci dapat disampaikan sebagai berikut: (a) siswa dapat menemukan ide lebih cepat, (b) siswa dapat membuat kerangka teks, (c) siswa dapat mengembangkan kerangka teks, (d) siswa dapat memerinci objek, (e) siswa semakin antusias dalam mengikuti pembelajaran menulis teks, (f) siswa paham melakukan proses menyusun teks deskripsi.

Pada saat dilakukan pembelajaran menulis teks deskripsi dengan menggunakan pendekatan proses menunjukkan adanya perubahan sikap yang lebih baik daripada sebelum dilakukan tindakan. Pembelajaran dengan menggunakan pendekatan proses meningkatkan motivasi menulis teks deskripsi siswa. Siswa menjadi lebih bersemangat.

Sebelum diberi tindakan kemampuan menulis siswa sangat kurang dengan rata-rata skor teks deskripsi siswa 60 dengan skor terendah 50 dan skor tertinggi 75. Setelah diberi tindakan, yaitu pada siklus pertama, kemampuan menulis siswa cukup meningkat dengan rata-rata skor teks deskripsi siswa adalah 66,7 dengan skor terendah 5 dan skor tertinggi 75. Setelah diberi tindakan kedua, yaitu pada siklus kedua, kemampuan menulis siswa lebih meningkat dengan rata-rata skor teks deskripsi adalah 70,8 dengan skor terendah 68 dan skor tertinggi sebesar 76. Sementara itu, setelah diberi tindakan ketiga, yaitu pada siklus ketiga, kemampuan menulis siswa lebih meningkat dengan rata-rata skor teks deskripsi adalah 78 dengan skor terendah 69 dan skor tertinggi sebesar 83 .

\section{DAFTAR PUSTAKA}

Akhadiah, S., Arsjad M. \& H. Ridwan, S. 1988. Pembinaan Kemampuan Bahasa Indonesia. Jakarta: Erlangga. 
Alpian, M., \& Suryaman, M. 2016. Pengaruh motivasi, keyakinan diri, dan persepsi siswa terhadap apresiasi karya sastra siswa SMP. LingTera, 3(1), 6074. doi:http://dx.doi.org/10.21831/ 1t.v3i1.8663

Alwasilah, A.C. dan Alwasilah, S.S. 2013. Pokoknya menulis: Cara baru menulis dengan metode kolaborasi. Bandung: Kiblat.

Hamalik, O. 2001. Proses Belajar Mengajar. Jakarta: Bumi Aksara.

Keraf, G. 1995. Eksposisi dan Deskripsi. Ende Flores: Nusa Indah.

Korb, R. 2012. Motivating Defiant \& Disruptive Students to Learn. California: Corwin

Mustafa, D., \& Efendi, A. 2016. Pengembangan Bahan Ajar Pembelajaran Menulis Cerita Berbasis Pendekatan Proses bagi Siswa SMP. LingTera, 3(1), 1-8. doi:http://dx.doi.org/10.21831/ 1t.v3i1.8469

Sabet, M. K. \& Abdorreza T. 2014. The Impact of Task-Based Approach On Iranian EFL Learners. Motivation In Writing Research Abstracts. English Department, University of Guilan, Rasht, Iran .ISSN 1798-4769 Journal of Language Teaching and Research, Vol. 5, No. 4, pp. 953-962, July 2014 (C) 2014 ACADEMY PUBLISHER Manufactured in Finland. doi:10.4304/jltr.5.4.953-962

Sanjana, W. 2006. Strategi pembelajaran berorientasi standar proses pendidikan. Jakarta: Kencana.

Sardiman, A.M. 2011. Interaksi dan Motivasi Belajar Mengajar. Jakarta: PT Raja Grafindo Jakarta.

Schunk, D.H. 2012. Teori-teori Pembelajaran. (Terjemahan Eva Hamdiah dan Rahmat Fajar). Yogyakarta: Pustaka Pelajar. (Edisi asli diterbitkan th 2012 oleh Pearson Education. Inc. New Jersey Upper Saddle River).
Semi. A. 2007. Dasar-dasar Keterampilan Menulis. Bandung: Angkasa.

Shourafa, A.Al-.European Scientific Journal October edition vol.8, No.22 ISSN: 1857-7881 (Print) e-ISSN 1857-7431. The effect of motivation on jordanian 10th grade students' writing skill in English. Professor at the Mutah University, Jordan-Alkarak

Sutama, I. M. 2016. Pembelajaran Menulis. Yogyakarta: Pustaka Pelajar.

Tarigan, H. G. 2013. Menulis sebagai suatu Kemampuan Berbahasa. Bandung: Angkasa. Edisi Revisi.

Tompkins, G. E. 2010. Literacy for the 21st Century, a Ballanced Approach. Boston: Allyn Bacon. Ur, P. 2007. A Course in Language Teaching. Cambridge: Cambridge University Press.

Tompkins, G. E. \& Hoskisson K. 1995. Language Arts Content and Teaching Strategies. New Jersey: Merrill an imprint of Pentice Hall.

Trim, B. 2016. Menulis Pedia: Panduan Menulis untuk Mereka yang Insyaf Menulis. Bandung: Nuansa Cendekia.

Wardhana, W. A. 2007. Menyingkap Rahasia jadi Penulis. Yogyakarta: Pustaka Pelajar.

Wlodkowski, R. J. \& Jaynes, J. H. 2004. Hasrat untuk Belajar (Membantu Anak-anak Termotivasi dan Mencintai Belajar). Terjemahan Nur Setiyo Budi Widarto. Yogyakarta: Pustaka Pelajar. (Edisi asli diterbitkan dengan judul Eager to learn).

Zainurrahman. 2011. Menulis: Dari Teori hingga Praktik. Bandung: Alfabeta. 